\title{
The Global Community and Diplomatic Capital
}

\begin{abstract}
This chapter examines how persons can collaborate for the common good of the global community through participation in international non-governmental organisations, multinational corporations and intergovernmental organisations. It also explains the collaboration of researchers globally to develop knowledge by following well-established norms and protocols to build an interconnected corpus of publications that offer evidence for falsifiable propositions. An example of researchers contributing to global efforts for wellbeing is the Intergovernmental Panel on Climate Change. The chapter introduces the metaphor of diplomatic capital to represent institutions and norms designed to foster cross-cultural collaborations in order to strengthen capabilities of the global community to act together for the common good.
\end{abstract}

Keywords Diplomatic capital $\bullet$ International non-governmental organisations • Intergovernmental organisations $\bullet$ Collaborative research $\bullet$ Climate change

Some of the most pressing issues threatening wellbeing can be addressed only with coordinated global action. Obvious examples include promotion of sustainable development, regulation of international trade, protection of human 
rights, resettlement of refugees, prevention of pandemics, resolution of intercountry conflicts, global peacekeeping, counter-terrorism, emergency disaster relief and effective responses to the risks of climate change.

Nevertheless, there are domestic pressures for some nations to reduce their engagement with international collaborations. In June 2016, for example, a majority of voters in a UK referendum supported withdrawal from the European Union. Across the Atlantic one year later, President Trump gave notice that the United States will withdraw from the 2015 Paris Agreement on climate change mitigation, which it had signed with 194 other countries in 2016-2017, on the grounds that he could "put no other consideration before the wellbeing of American citizens” (Trump 2017).

These examples reflect a tension that is common in collaborations among countries. Similar to the street lighting example in Chap. 6, citizens may calculate that their country's share of the costs of an international project is greater than the extra benefits they receive from making that sacrifice, and so vote to withdraw from the project. If a majority of citizens in enough countries reason the same way, the collaboration may collapse with all benefits lost, even if total benefits clearly outweigh total costs. ${ }^{1}$

This chapter therefore examines how persons are able to engage with collaboration for the common good of the global community, focusing on climate change as a case study. It begins with a description of three avenues for collaboration that echo, at the international level, the analysis in previous chapters of civil society institutions, market firms and government agencies. The second section then considers another significant collaboration on the world stage-the work of researchers engaged in creating and testing new knowledge. This human institution of collaborative research provides foundations for fostering many other types of international co-operation.

The remainder of the chapter then explores these ideas further using the example of global climate change. The Intergovernmental Panel on Climate Change (IPCC) illustrates how new organisations are being developed for the creation and communication of reliable knowledge. The consensus of the research community on climate change, for example, is very strong: "Warming of the climate system is unequivocal, and since the 1950s, many of the observed changes are unprecedented over decades to millennia" (IPCC 2014, p. 2). The final section of the chapter, before a brief conclusion, addresses the challenge of achieving effective responses to that scientific knowledge. It introduces the metaphor of diplomatic capital to represent institutions and norms that foster crosscultural collaborations for the common good. 


\section{Collaboration in the Global Community}

The world population in 2017 was 7.6 billion persons and might reach 11.2 billion by 2100 (United Nations 2017, Table 1, p. 1). Such large numbers mean that effective actions at a global level require international institutions. Previous chapters have analysed how persons within a Nation State can collaborate through civil society institutions, market firms and different levels of government. Similarly, people can participate in three types of global institutions: international non-governmental organisations (INGOs), multinational corporations $(\mathrm{MNCs})^{2}$ and intergovernmental organisations (IGOs). Based on that classification, this section provides evidence in support of the following proposition.

Proposition 22 International non-governmental organisations, multinational corporations and intergovernmental organisations can increase opportunities for global collaboration.

The number of active international non-governmental organisations increased sharply after World War II. Boli and Thomas (1997), for example, analysed INGOs going back to 1875 . They found records for about 200 INGOs in 1900, rising to around 800 in 1930. This figure jumped to more than 2000 active INGOs in 1960, and to more than 4000 by 1980 (idem, p. 172; see also Clark 1995).

Although 20 years old, the data analysed by Boli and Thomas (1997) illustrate a broad range of INGO activities (see Fig. 8.1). They include associations promoting business and economic development, organisations supporting scientific knowledge and technique, international bodies managing sports, hobbies or other leisure activities, and groups advocating for protection of individual rights and other world causes such as environmental preservation (idem, pp. 182-184).

An example of an INGO that attracts support from millions of persons is the International Red Cross and Red Crescent Movement (ICRC 2014). This is one of the oldest INGOs still in operation. It began after publication of a book in 1862 by Swiss businessman Henry Dunant, in which he reported his witness of the suffering of combatants left to die after the Battle of Solferino. He appealed for organised humanitarian responses beyond ad hoc charity, which led to the creation of the International Committee of the Red Cross in October 1863 and the adoption of the first Geneva Convention concerning war conduct on 22 August 1864 (Bernard 2012, pp. 1198-1199). 


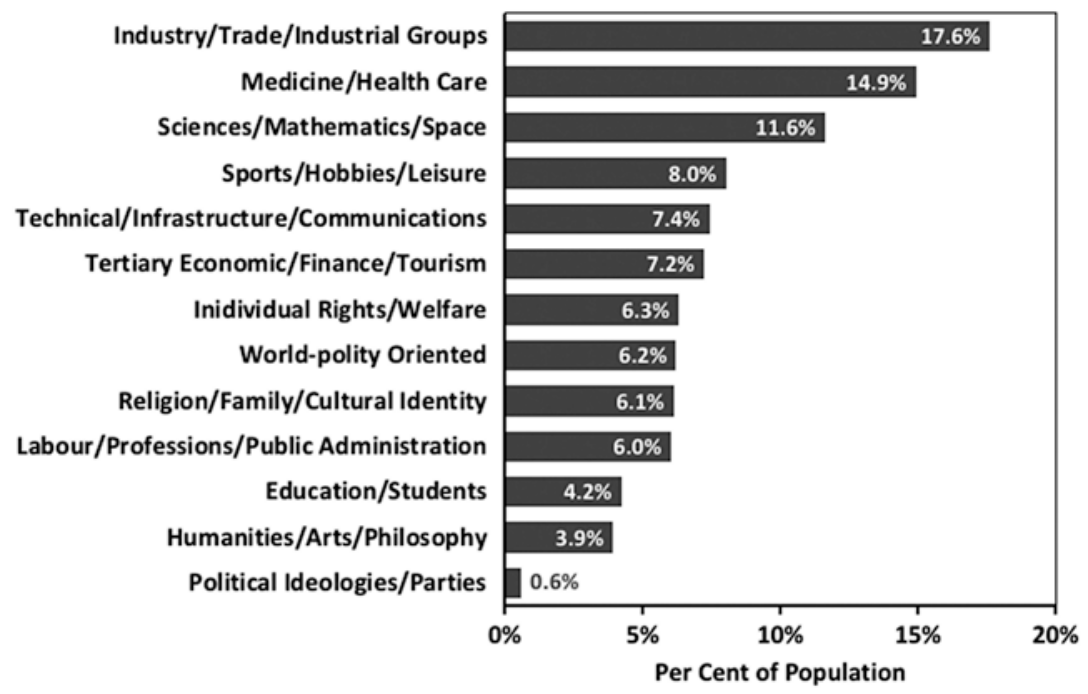

Fig. 8.1 Percentage distribution of active international non-governmental organisations by sector, 1988. (Source: Boli and Thomas (1997, Fig. 2, using UIA (1988) data, p. 183))

More than 150 years later, there are 189 Red Cross and Red Crescent Societies around the world, united by seven fundamental principles: humanity, impartiality, neutrality, independence, voluntary service, unity and universality (ICRC 2014). Donors and volunteers support the Movement's mission of alleviating human suffering, protecting life and health, and upholding human dignity, especially during armed conflicts, natural disasters and other emergencies. Similarly, the Geneva Convention, extended over the decades, is now supported by 196 state parties (ICRC 2018).

MNCs play dominant roles in the global economy (Narula and Dunning 2000; Mudambi and Santangelo 2016; Forsgren 2017). Their number has also greatly increased in recent decades. Gabel and Henry (2003, p. 3) estimate that there were around $7000 \mathrm{MNCs}$ in 1970, which jumped to around 30,000 in 1990 and 63,000 in 2000. This growth was part of the deeper process of economic globalisation that created an integrated global economy (IMF 2008, p. 2). In 2016, the 100 largest MNCs (excluding financial corporations) employed 16.3 million persons and owned assets valued above US $\$ 13$ trillion (UNCTAD 2017, Table 1.5 , p. 29).

Some MNCs are criticised for pursuing shareholder wealth at the expense of awful damage to the wellbeing of partners, workers and other stakeholders, espe- 
cially in developing countries (Banks et al. 2015; Omoteso and Yusuf 2017). As a counter to that behaviour, individuals are able to support corporate social responsibility by acting as ethical consumers (Chipulu et al. 2018) or as socially responsible investors (Riedl and Smeets 2017). The fundamental motivation for corporate social responsibility is ethical, but there is solid evidence that it can also contribute to better financial performance (Chernev and Blair 2015; Crifo and Forget 2015; Saeidi et al. 2015; Wang et al. 2016; Jamali and Karam 2018).

Some MNCs are responding to the ethical expectations of customers and shareholders by using ethical labels to communicate their performance standards (Hartlieb and Jones 2009; Bissinger and Leufkens 2017). The Sustainability Consortium is an example of a global business-led initiative that is using scientific knowledge to help companies provide consumer products while respecting the environmental limits of the planet. ${ }^{3}$

The third category of global collaborations involves IGOs established for specific purposes by treaty or charter ratified by Nation States. These include prominent agencies focused on aspects of the global economy, including the Bank for International Settlements (established in 1930), the World Bank (1944), the International Monetary Fund (1945) and the World Trade Organisation (1995). Like INGOs and MNCs, the number of IGOs grew strongly after World War II. Held and McGrew (2007, p. 22) note that just 36 were recorded at the beginning of the twentieth century, but the number had reached 7350 by 2000 , with most of that increase occurring after 1978 (see also UIA 2001).

The European Union is an IGO. The United Kingdom acceded to the European Economic Community (EEC) on 1 January 1973, and hence was a founding member of the European Union when it replaced the EEC in the Maastricht Treaty 20 years later. Article B of the Treaty records that the Union's five objectives are based on economic and social progress, international identity, the rights and interests of citizens, co-operation on justice and home affairs, and building on the Union's legal order. A majority of voters in the UK 2016 referendum were in favour of leaving the Union, so that Britain gave notice of its withdrawal by 29 March 2019.

The United Nations is another prominent IGO, created after World War II by a Charter that is currently ratified by 193 Member States. ${ }^{4}$ The Charter sets out the organisation's purposes, which translate into five areas of activity undertaken with the global community:

- Maintain international peace and security

- Protect human rights 
- Deliver humanitarian aid

- Promote sustainable development

- Uphold international law

United Nations' programmes for sustainable development are particularly relevant to the themes of this book. Indeed, the description of this aspect of its mission resonates strongly with the wellbeing economics framework (United Nations 2018):

Improving people's well-being continues to be one of the main focuses of the UN. The global understanding of development has changed over the years, and countries now have agreed that sustainable development - development that promotes prosperity and economic opportunity, greater social well-being, and protection of the environment - offers the best path forward for improving the lives of people everywhere.

To mark the beginning of third millennium, the United Nations General Assembly adopted eight Millennium Development Goals (MDGs), accompanied by specific targets for progress by 2015 (United Nations 2001). That initiative mobilised global efforts that "helped to lift more than one billion people out of extreme poverty, to make inroads against hunger, to enable more girls to attend school than ever before and to protect our planet" (United Nations $2015 \mathrm{a}$, p. 3). This illustrates the potential of global collaboration to enhance wellbeing, although there remain powerful interests working against global social justice. Following the achievements of the MDGs programme, the General Assembly adopted the 2030 Agenda for Sustainable Development, which sets out 17 Sustainable Development Goals and 169 targets (United Nations 2015b).

\section{The Global Community of Researchers}

Chap. 7 highlighted the contribution that knowledge can make to wellbeing, also observing that the creation of new knowledge is a global activity. The scale of collaboration required for discovering and testing new knowledge is demanding. It is made possible by developing norms and protocols that build confidence in scientific knowledge, despite researchers working in diverse institutions, cultures and countries. Widespread trust that the global research community is producing reliable knowledge is necessary for other forms of international collaborations. 
Like the three groups considered in the previous section, there was a large expansion in organisations contributing to new knowledge during the latter half of the twentieth century. This was the result of increasing access to tertiary education, accompanied by the creation of a greater number and wider range of non-university research groups (Gibbons et al. 1994, p. 11):

The massification of higher education and the appropriation, after the Second World War, by the universities of a distinct research function have produced increasing numbers of people familiar with the methods of research, many of whom are equipped with specialised knowledge and skills of various kinds.... Scientific and technological knowledge production are now pursued not only in universities but also in industry and government laboratories, in think-tanks, research institutions and consultancies, etc.

Universities continue to be a key source of new knowledge. In the United Kingdom, 154 universities were included in the 2014 assessment of the Research Excellence Framework. That assessment covered 52,061 academic staff, 191,150 research outputs published between 2008 and 2013, and 6975 case studies of impacts beyond academia (REF 2014). Another indicator of global scale comes from the QS World University Rankings in 2018, which featured 959 universities from 84 countries. ${ }^{5}$

An important issue is that researchers generally accept that there is no method for demonstrating with certainty that any scientific hypothesis is true (Nola and Sankey 2000). Progress in developing a body of scientific knowledge is nevertheless possible, achieved through the practice of publishing research results in journals and books. Karl Popper (1983, p. xxxv) famously suggested that this is a distinctive feature of human knowledge:

The special thing about human knowledge is that it may be formulated in language, in propositions. This makes it possible for knowledge to become conscious and to be objectively criticisable by arguments and by tests. In this way we arrive at science.

Knowledge develops through the publication of results that are open to testing, refutation and further development by any researcher (Popper 1959, p. 41). There are strong norms and protocols for research publications. The research question must be clearly stated, for example, and its importance explained. Relevant publications that previously addressed the issue must be cited. The research method used to test the new knowledge claim must be described, so 
that the evidence is replicable by other researchers. Conclusions must not reach beyond what the evidence justifies.

The best research outputs are peer reviewed, meaning that manuscripts are assessed by qualified researchers before acceptance for publication. Further, the practice of citing relevant research means the corpus of scientific knowledge is strongly interconnected as it expands. Clarivate Analytics, for example, maintains an important citations database (the Web of Science Core Collection; see http://clarivate.libguides.com/home) as a curated collection of more than 18,000 peer-reviewed, high-quality scholarly journals representing more than 250 research disciplines. This database has tracked well over one billion cited references going back to 1900 .

Proposition 23 The global research community can develop knowledge by following well-established norms and protocols to build an interconnected corpus of publications that offer evidence for falsifiable propositions.

Popper (1959, p. 13) observed that researchers approach problems within "a structure of scientific doctrines [that] is already in existence; and with it, a generally accepted problem-situation". Thomas Kuhn (1962) introduced the word paradigm to describe this feature of what he termed "normal science". Researchers address problems within their adopted paradigm, recognising that occasionally a crisis may produce a scientific revolution. Imre Lakatos (1970) went further, arguing that normal science typically involves a hard core of theories accepted by adherents, defended by a "protective belt of auxiliary hypotheses" that is the focus of research effort. ${ }^{6}$

In this tradition, the economics discipline has a strong theoretical core. Its central paradigm has been fruitful in creating knowledge, but is also challenged by feminist scholars (among others) for being founded on gender-blind methodological individualism and for emphasising questions affecting the market economy at the expense of other important problems of wellbeing, such as those related to household economies. ${ }^{7}$ The economics community recognises feminist economics as a valid field of research, but categorises it under the heading of "Current Heterodox Approaches" (American Economic Association 2017, category B54). Thus, feminist economics is explicitly labelled as outside the discipline's orthodox paradigm. This example illustrates that a research community does not operate in a vacuum. Like other global collaborations, research is influenced by the political, economic, social, cultural and technological forces of the times. 


\section{The Science of Global Climate Change}

Researchers have recognised that knowledge production has been extending from its traditional context of individual research disciplines into a new mode where "knowledge is created in broader, transdisciplinary social and economic contexts" (Gibbons et al. 1994, p. 1; see also Ledford 2015). This is resulting in new institutions for creating, synthesising and communicating knowledge. An outstanding example concerns the science of global climate change, where the IPCC has been created to support collaboration across research disciplines and among researchers from different cultures and countries.

The World Meteorological Organization and the United Nations Environmental Programme jointly established the IPCC in 1988 (Agrawala 1998a, p. 606). It followed the signing of the Montreal Protocol in 1987, in which countries had agreed to phase out the production of substances that scientists had demonstrated were responsible for ozone depletion in the atmosphere (see Murdoch and Sandler 1997; Douglass et al. 2014). The IPCC is currently supported by 195 countries. $^{8}$

The United Nations General Assembly of 1998 endorsed the IPCC initiative, and commissioned it to produce a comprehensive review on five matters which continue to frame its mission (IPCC 2010, p. 4):

(a) The state of knowledge of the science of climate and climatic change;

(b) Programmes and studies on the social and economic impact of climate change, including global warming;

(c) Possible response strategies to delay, limit or mitigate the impact of adverse climate change;

(d) The identification and possible strengthening of relevant existing international legal instruments having a bearing on climate;

(e) Elements for inclusion in a possible future international convention on climate.

The IPCC published five assessment reports between 1990 and 2014. It is working on a sixth, and also produces technical papers and special reports. These outputs rely on the co-operation of thousands of experts from all regions of the world (IPCC 2010, p. 1). Following accepted norms for research publications, peer review is an essential element of its work programme, as observed by Agrawala (1998b, p. 623-624, emphasis in the original): 
However, the IPCC peer review is more comprehensive, by many orders of magnitude, than that in an average journal. For example, draft chapters of the 1995 Working Group II Second Assessment report went through two full scale reviews: the first involving anywhere from twenty to sixty expert reviewers per chapter (a total of 700 experts from 58 countries were involved), and the second involving all IPCC member governments and the experts who had sent their reviews in the first round.

The IPCC is bound by the standard principles of scientific integrity, objectivity, openness and transparency. Another key principle is "to be policy relevant, but not policy prescriptive" (IPCC 2010, p. 1). The IPCC therefore places strong emphasis on communication. Major reports begin with a summary for policymakers and include key graphics to illustrate the science.

The Fifth Assessment Report was based on a synthesis of physical science research relevant to climate change (IPCC 2013). It brought together ten indicators of a changing global climate (idem, Fig. TS.1, p. 38), including five going back to the beginning of the nineteenth century: land surface air temperature; sea surface temperature; marine air temperature; sea level; and summer arctic sea-ice extent. The scientific conclusion was clear (idem, p. 4):

Warming of the climate system is unequivocal, and since the 1950s, many of the observed changes are unprecedented over decades to millennia. The atmosphere and ocean have warmed, the amounts of snow and ice have diminished, sea level has risen, and the concentrations of greenhouse gases have increased.

The higher concentration of greenhouse gases is significant because it is a major driver of surface warming and global climate change through radiative forcing (see IPCC 2013, pp.13-14). The largest contribution comes from carbon dioxide $\left(\mathrm{CO}_{2}\right)$ emissions. The IPCC has therefore collated data on the increased concentration of $\mathrm{CO}_{2}$ in the atmosphere since 1958. ${ }^{9}$ Again, the scientific conclusion is clear (idem, p. 11):

The atmospheric concentrations of carbon dioxide, methane, and nitrous oxide have increased to levels unprecedented in at least the last 800,000 years. Carbon dioxide concentrations have increased by $40 \%$ since pre-industrial times, primarily from fossil fuel emissions and secondarily from net land use change emissions. The ocean has absorbed about $30 \%$ of the emitted anthropogenic carbon dioxide, causing ocean acidification.

Five specific reasons for concern guide the IPCC's risk analysis of climate change (IPCC 2014, Box 2.4, p. 72). A higher mean temperature of the globe 
produces: (1) greater risks of severe consequence for certain ecosystems and cultures; (2) a greater likelihood of extreme weather events such as droughts and storms; (3) greater risks of unevenly distributed impacts on disadvantaged people and communities; (4) a greater likelihood of adverse aggregate impacts globally; and (5) a greater likelihood that some physical and ecological systems will experience abrupt or irreversible changes.

In one of its most important graphics (see IPCC 2014, Fig. 3.1, p. 78), the IPCC links each of these five risks to the range of plausible changes in the earth's global mean temperature by 2050, relative to its value at the beginning of the industrial revolution. This is affected by cumulative anthropogenic $\mathrm{CO}_{2}$ emissions, which depend in turn on annual greenhouse gas emissions over the next decades.

The analysis indicates that if greenhouse gas emissions are kept to their 2010 level, the cumulative anthropogenic $\mathrm{CO}_{2}$ emissions in 2050 are likely to be in the order of 4000 to 5000 Gigatonnes of carbon dioxide, which is associated with a likely temperature rise of about $2.5^{\circ} \mathrm{C}$ relative to pre-industrial levels. The first decade of this century saw an increase of between $0.5^{\circ} \mathrm{C}$ and $1.0{ }^{\circ} \mathrm{C}$, so the scientific analysis implies that human-induced climate change will create substantially increased risks for future generations of adverse impacts in all of the five reasons for concern.

This evidence provides compelling reasons for responses by actors in the global community, but the situation is more urgent than the previous paragraph might suggest. This is because greenhouse gas emissions are unlikely to remain at their 2010 level without deliberate action, since governments around the world are committed to economic growth. If nothing else changes, growth can be expected to increase greenhouse gas emissions.

Consequently, the baseline scenario in the IPPC risk analysis reveals that on current growth paths, the global mean temperature by 2050 may be $4{ }^{\circ} \mathrm{C}$ higher than pre-industrial levels. The IPCC (2014, p. 17) therefore concludes with high confidence:

Without additional mitigation efforts beyond those in place today, and even with adaptation, warming by the end of the 21 st century will lead to high to very high risk of severe, widespread and irreversible impacts globally.

Philosophers have argued that it is unethical for humanity to change the climate of the planet to this extent (Palmer 2011). In any case, the risks identified by the IPCC represent a major threat to future human wellbeing on a global scale, which raises its own ethical challenges (Gardiner 2004; Nordhaus 2007; 
Weitzman 2007; Stern 2008). What is clear is that effective responses to mitigate climate change will require coordinated action around the world. The final section of this chapter addresses how this might be achieved.

\section{Diplomatic Capital}

A useful starting point for considering globally coordinated responses to the threats of climate change is the Paris Agreement that came into force on 4 November 2016. ${ }^{10}$ The Agreement is comprised of a preamble and 29 articles. Building on the United Nations Framework Convention on Climate Change adopted in 1992, its specific aim recorded in Article 2 is "to strengthen the global response to the threat of climate change, in the context of sustainable development and efforts to eradicate poverty", including by:

Holding the increase in the global average temperature to well below $2^{\circ} \mathrm{C}$ above pre-industrial levels and pursuing efforts to limit the temperature increase to $1.5^{\circ} \mathrm{C}$ above pre-industrial levels, recognizing that this would significantly reduce the risks and impacts of climate change.

Based on the IPCC analysis discussed above, these targets are necessary to keep the risks from a higher global temperature to moderate levels, but they also require greenhouse gas emissions to return below their 1990 levels. The Agreement does not state how this will be achieved, leaving this for Nation States to decide (Article 3, emphasis added):

As nationally determined contributions to the global response to climate change, all Parties are to undertake and communicate ambitious efforts as defined in Articles $4,7,9,10,11$ and 13 with the view to achieving the purpose of this Agreement as set out in Article 2.

Note the reference to ambitious efforts. The task of reducing greenhouse gas emissions is indeed challenging, especially in the context of national aspirations for economic growth (Jackson 2017). A further challenge is that damage from emissions is an example of "the tragedy of the commons" (Hardin 1968; Ostrom 1990; Paavola 2008). A commons is a resource where no effective mechanism had been created for preventing anyone from freely consuming the resource. A classic example of a commons is an ocean fishery, where economic analysis and 
numerous case studies demonstrate that the incentives in the market economy for conserving fish stocks are very weak (Gordon 1954; McWhinnie 2009).

The earth's atmosphere is another example of a commons. Consequently, any nation agreeing to implement costly policies to reduce its share of damaging greenhouse gas emissions may reasonably worry about what will prevent other nations from taking advantage by increasing their own emissions. This is an example of the Prisoner's Dilemma (see this chapter's footnote 1). A solution requires effective mechanisms for ensuring universal compliance to agreements made about management of the resource (Ostrom 1990). In the case of global climate change, this may require new systems of "earth system governance" (Biermann 2012 and 2018; Dryzek 2016; Galaz et al. 2012).

Effective collaboration will involve new IGOs, but civil society organisations will also have important roles (Iati 2008). This was reflected, for example, in the International NGO Forum on Climate Change hosted by UNESCO in December 2017, involving more than 300 representatives of civil society. ${ }^{11}$ Similarly, as discussed above, at least some MNCs are recognising that they must reduce their environment impacts for economic activities to be sustainable.

Chap. 4 introduced the metaphor of social capital to represent the idea that social collaboration is easier when residents in a nation are connected to each other through social networks and sharing social norms. Similarly, global collaboration is easier when relevant institutions and norms strengthen capabilities for cross-cultural common action. Echoing previous uses of the term "environmental diplomacy" in this context (see, e.g., Carroll 1988; Broadhurst and Ledgerwood 1998; Susskind and Ali 2015), Proposition 24 offers the phrase diplomatic capital as a metaphor to describe this concept.

Proposition 24 Investment in diplomatic capital (i.e., in institutions and norms designed to foster cross-cultural collaborations) can strengthen the capabilities of the global community to act together for the common good.

Institutions and norms of state diplomacy have been developed over centuries to support co-operation between countries (Anderson 1993). This is an example of investment in diplomatic capital, but all international organisations must similarly develop norms and protocols to be effective. The seven fundamental principles accepted by members of the International Red Cross and Red Crescent Movement, discussed earlier in this chapter, is an obvious example. Similarly, the difficulties and rewards of drawing on cultural differences business enterprises is well recognised (Shenkar 2001). In short, any initiative that brings 
together diverse actors to address a global issue requires diplomatic capital to succeed.

\section{Conclusion}

Persons engage with global issues through specialist institutions that aim to foster collaboration on the world stage. These institutions include INGOs, MNCs and IGOs. Some institutions have undertaken activities that damage wellbeing, particularly in developing countries. Nevertheless, it is clear that some issues affecting the common good of the global community cannot be solved without coordinated efforts from diverse countries, large corporations and representatives of civil society.

The capability to foster global collaboration must not be taken for granted. In the language of this chapter, it requires conscious investment in diplomatic capital, defined as institutions and norms designed to foster cross-cultural collaborations. This applies not only to diplomatic relations among countries but to all initiatives that bring together diverse actors to address global issues.

An important example is the work of the global research community. Researchers have developed norms and protocols that build confidence in the quality of the new knowledge created by research. New institutions are being created to engage in transdisciplinary research on issues affecting the wellbeing of billions of people. The work of the IPCC is an outstanding example.

Nevertheless, there are stresses evident in global collaborations. This chapter began by noting the withdrawal of the United Kingdom from the European Union and the withdrawal of the United States from the Paris Agreement. These events suggest that the current stock of diplomatic capital has been inadequate for meeting some urgent global challenges connected to sustainable development and climate change. Stronger institutions and norms will be needed in the future.

\section{Notes}

1. In the language of economists, this is the Prisoner's Dilemma problem, in which isolated and self-interested individuals are unable to achieve a collaborative solution that would make each better off. Soroos (1994) warned that this could be a good representation of international negotiations to address climate change, and suggested reasons why the United States might not collaborate (idem, p. 329). 
2. There are subtle and contested differences in the usage of terms such as multinational, transnational, stateless or global corporations (Hu 1992). This is not important for this chapter; the analysis could have used any of these terms.

3. See https://www.sustainabilityconsortium.org/, accessed 26 February 2018.

4. The material in these paragraphs is sourced from the United Nations website, www.un.org/, accessed 26 February 2018.

5. Data accessed from https://www.topuniversities.com/university-rankings-articles/world-university-rankings/out-now-qs-world-university-rankings-2018, 28 February 2018.

6. Maxwell $(1998,2005)$ has argued that the insights of Popper, Kuhn and Lakatos can be synthesised into a theory of science he terms aim-oriented empiricism. This suggestion is noted but not pursued here.

7. See, for example, Boserup (1970), Folbre and Hartmann (1988), Waring (1988), Ferber and Nelson (1993, 2003), MacDonald (1995), Bjørnholt and McKay (2014), Gammage et al. (2016) and Saunders and Dalziel (2017). One woman has received the Nobel Prize in Economics (Elinor Ostrom 2010).

8. See www.ipcc.ch/organization/organization.shtml, accessed 25 February 2018.

9. It also publishes data on the increased partial pressure of dissolved $\mathrm{CO}_{2}$ at the ocean surface and increased acidity of ocean water (reduced $\mathrm{pH}$ levels) since 1988 (see, e.g., IPCC 2014, Fig. SPM.4, p. 12).

10. See http://unfccc.int/paris_agreement/items/9444.php, accessed 25 February 2018.

11. See https://en.unesco.org/news/unesco-hosts-international-ngo-forum-climatechange, accessed 26 February 2018.

\section{References}

Agrawala, Shardul. 1998a. Context and Early Origins of the Intergovernmental Panel on Climate Change. Climate Change 39 (4): 605-620.

- 1998b. Structural and Process History of the Intergovernmental Panel on Climate Change. Climate Change 39 (4): 621-642.

American Economic Association. 2017. JEL Classification System / EconLit Subject Descriptors. https://www.aeaweb.org/econlit/jelCodes.php. Webpage Accessed 23 Feb 2018.

Anderson, Matthew S. 1993. The Rise of Modern Diplomacy 1450-1919. London: Longman.

Banks, Nicola, David Hulme, and Michael Edwards. 2015. NGOs, States, and Donors Revisited: Still Too Close for Comfort? World Development 66 (February): 707-718. Bernard, Vincent. 2012. Editorial: The Quest for Humanity 150 Years of International Humanitarian Law and Action. International Review of the Red Cross 94 (888): $1195-1207$. 
Biermann, Frank. 2012. Planetary Boundaries and Earth System Governance: Exploring the Links. Ecological Economics 81: 4-9.

- 2018. Global Governance in the "Anthropocene". In The Oxford Handbook of International Political Theory, ed. Chris Brown and Robyn Eckersley, 467-478. Oxford: Oxford University Press.

Bissinger, Katharina, and Daniel Leufkens. 2017. Ethical Food Labels in Consumer Preferences. British Food Journal 119 (8): 1801-1814.

Bjørnholt, Margunn, and Ailsa McKay, eds. 2014. Counting on Marilyn Waring: New Advances in Feminist Economics. Bradford: Demeter Press.

Boli, John, and George M. Thomas. 1997. World Culture in the World Polity: A Century of International Non-Governmental Organization. American Sociological Review 62 (2): 171-190.

Boserup, Ester. 1970. Woman's Role in Economic Development. New York: St. Martin's Press.

Broadhurst, Arlene I., and Grant Ledgerwood. 1998. Environmental Diplomacy of States, Corporations and Non-Governmental Organisations: The Worldwide Web of Influence. International Relations 14 (2): 1-19.

Carroll, John E. 1988. International Environmental Diplomacy: The Management and Resolution of Transfrontier Environmental Problems. Cambridge: Cambridge University Press.

Chernev, Alexander, and Sean Blair. 2015. Doing Well by Doing Good: The Benevolent Halo of Corporate Social Responsibility. Journal of Consumer Research 41 (6): 1412-1425.

Chipulu, Maxwell, Alasdair Marshall, Udechukwu Ojiako, and Caroline Mota. 2018. Reasoned Ethical Engagement: Ethical Values of Consumers as Primary Antecedents of Instrumental Actions Towards Multinationals. Journal of Business Ethics 147 (1): 221-238.

Clark, Ann Marie. 1995. Non-Governmental Organizations and their Influence on International Society. Journal of International Affairs 48 (2): 507-525.

Crifo, Patricia, and Vanina D. Forget. 2015. The Responsibility of Corporate Social Responsibility: A Firm-Level Perspective Survey. Journal of Economic Surveys 29 (1): 112-130.

Douglass, Anne R., Paul A. Newman, and Susan Solomon. 2014. The Antarctic Ozone Hole: An Update. Physics Today 67 (7): 42-47.

Dryzek, John S. 2016. Institutions for the Anthropocene: Governance in a Changing Earth System. British Journal of Political Science 46 (4): 937-956.

Dunant, Henry. 1862. Un Souvenir de Solférino. Genève: Jules-Guillaume Fick. Trans. and Published as A Memory of Solferino by the American Red Cross, 1939.

Ferber, Marianne A., and Julie A. Nelson, eds. 1993. Beyond Economic Man: Feminist Theory and Economics. Chicago: University of Chicago Press.

—_ eds. 2003. Feminist Economics Today: Beyond Economic Man. Chicago: University of Chicago Press. 
Folbre, Nancy, and Heidi Hartmann. 1988. The Rhetoric of Self-interest: Ideology and Gender in Economic Theory. In The Consequences of Economic Rhetoric, ed. Arjo Klamer, Deirdre N. McCloskey, and Robert M. Solow, 184-203. Cambridge: Cambridge University Press.

Forsgren, Mats. 2017. Theories of the Multinational Firm: A Multidimensional Creature in the Global Economy. Third ed. Cheltenham: Edward Elgar.

Gabel, Medard, and Henry Bruner. 2003. Global Inc. An Atlas of the Multinational Corporation. New York: The New Press.

Galaz, Victor, Beatrice Crona, Henrik Österblom, Per Olsson, and Carl Folke. 2012. Polycentric Systems and Interacting Planetary Boundaries - Emerging Governance of Climate Change-Ocean Acidification-Marine Biodiversity. Ecological Economics 81: $21-32$.

Gammage, Sarah, Naila Kabeer, and Yana van der Meulen Rodgers. 2016. Voice and Agency: Where Are We Now? Feminist Economics 22 (1): 1-29.

Gardiner, Stephen M. 2004. Ethics and Global Climate Change. Ethics 114 (3): $555-600$.

Gordon, H. Scott. 1954. The Economic Theory of a Common-Property Resource: The Fishery. Journal of Political Economy 62 (2): 124-142.

Gibbons, Michael, Camille Limoges, Helga Nowotny, Simon Schwartzman, Peter Scott, and Martin Trow. 1994. The New Production of Knowledge: The Dynamics of Science and Research in Contemporary Societies. London: SAGE Publications.

Hardin, Garrett. 1968. The Tragedy of the Commons. Science 162 (3859): 1243-1248. Hartlieb, Susanne, and Bryn Jones. 2009. Humanising Business through Ethical Labelling: Progress and Paradoxes in the UK. Journal of Business Ethics 88 (3): 583-600.

Held, David, and Anthony McGrew. 2007. Globalization/Anti-Globalization: Beyond the Great Divide. Second ed. Cambridge: Polity Press.

$\mathrm{Hu}$, Yao-Su. 1992. Global or Stateless Corporations are National Firms with International Operations. California Management Review 34 (2): 107-126.

Iati, Iati. 2008. The Potential of Civil Society in Climate Change Adaptation Strategies. Political Science 60 (1): 19-30.

ICRC. 2014. The Fundamental Principles of the International Red Cross and Red Crescent Movement. Pamphlet published by ICRC. Geneva: International Committee of the Red Cross.

- 2018. State Parties to the Following International Humanitarian Law and Other Related Treaties as of 2-Feb-2018. Geneva: International Committee of the Red Cross. https://ihl-databases.icrc.org/applic/ihl/ihl.nsf/vwTreaties1949.xsp. Accessed 12 Feb 2018.

IMF. 2008. Globalization: A Brief Overview. International Monetary Fund Issues Brief 02/08, May: $1-8$.

IPCC. 2010. Understanding Climate Change: 22 Years of IPCC Assessment. Pamphlet published by the IPCC. Geneva: Intergovernmental Panel on Climate Change. 
- 2013. Climate Change 2013: The Physical Science Basis. Contribution of Working Group I to the Fifth Assessment Report of the Intergovernmental Panel on Climate Change. Cambridge/New York: Cambridge University Press.

- 2014. Climate Change 2014: Synthesis Report. Contribution of Working Groups I, II and III to the Fifth Assessment Report of the IPCC. Geneva: Intergovernmental Panel on Climate Change.

Jackson, Tim. 2017. Prosperity without Growth: Foundations for the Economy of Tomorrow. 2nd ed. Abingdon/New York: Routledge.

Jamali, Dima, and Charlotte Karam. 2018. Corporate Social Responsibility in Developing Countries as an Emerging Field of Study. International Journal of Management Reviews 20 (1): 32-61.

Kuhn, Thomas S. 1962. The Structure of Scientific Revolutions. Chicago: University of Chicago Press.

Lakatos, Imre. 1970. Falsification and the Methodology of Scientific Research Programmes. In Imre Lakatos and Alan Musgrave, Eds. Criticism and the Growth of Knowledge. Cambridge: Cambridge University Press, pp. 91-196. Reproduced as, and cited from, The Methodology of Scientific Research Programmes: Philosophical Papers, ed. John Worrall and Gregory Currie, Vol. 1, 205-259. Cambridge: Cambridge University Press, 1978.

Ledford, Heidi. 2015. How to Solve the World's Biggest Problems. Nature 525 (7569): 308-311.

MacDonald, Martha. 1995. Feminist Economics - From Theory to Research. Canadian Journal of Economics 28 (1): 159-176.

Maxwell, Nicholas. 1998. The Comprehensibility of the Universe: A New Conception of Science. Oxford: Oxford University Press.

- 2005. Popper, Kuhn, Lakatos and Aim-Oriented Empiricism. Philosophia 32 (1-4): 181-239.

McWhinnie, Stephanie F. 2009. The Tragedy of the Commons in International Fisheries: An Empirical Examination. Journal of Environmental Economics and Management 57 (3): 321-333.

Mudambi, Ram, and Grazia D. Santangelo. 2016. From Shallow Resource Pools to Emerging Clusters: The Role of Multinational Enterprise Subsidiaries in Peripheral Areas. Regional Studies 50 (12): 1965-1979.

Murdoch, James C., and Todd Sandler. 1997. The Voluntary Provision of a Pure Public Good: The Case of Reduced CFC Emissions and the Montreal Protocol. Journal of Public Economics 63 (3): 331-349.

Narula, Rajneesh, and John H. Dunning. 2000. Industrial Development, Globalization and Multinational Enterprises: New Realities for Developing Countries. Oxford Development Studies 28 (2): 141-167.

Nola, Robert, and Howard Sankey. 2000. A Selective Survey of Theories of Scientific Method. In After Popper, Kuhn and Feyerabend: Recent Issues in Theories of Scientific Method, ed. Robert Nola and Howard Sankey, 1-65. Dordrecht: Kluwer Academic Publishers. 
Nordhaus, William D. 2007. A Review of the Stern Review on the Economics of Climate Change. Journal of Economic Literature 45 (3): 686-702.

Omoteso, Kamil, and Hakeem Yusuf. 2017. Accountability of Transnational Corporations in the Developing World: The Case for an Enforceable International Mechanism. Critical Perspectives on International Business 13 (1): 54-71.

Ostrom, Elinor. 1990. Governing the Commons: The Evolution of Institutions for Collective Action. Cambridge: Cambridge University Press.

- 2010. Beyond Markets and States: Polycentric Governance of Complex Economic Systems. American Economic Review 100 (3): 641-672.

Paavola, Jouni. 2008. Governing Atmospheric Sinks: The Architecture of Entitlements in the Global Commons. International Journal of the Commons 2 (2): 313-336.

Palmer, Clare. 2011. Does Nature Matter? The Place of the Nonhuman in the Ethics of Climate Change. In The Ethics of Global Climate Change, ed. Denis G. Arnold, 272-291. Cambridge: Cambridge University Press.

Popper, Karl R. 1959. The Logic of Scientific Discovery. A translation of Logik der Forschung published in 1934. New York: Basic Books.

-1983. Realism and the Aim of Science: From the Postscript to the Logic of Scientific Discovery, ed. W. W. Bartley, III. Oxon: Routledge.

REF. 2014. Key Facts, December 2014. Leaflet Published by the Research Excellence Framework. www.ref.ac.uk/2014/pubs/keyfacts/. Accessed 22 Feb 2018.

Riedl, A., and P. Smeets. 2017. Why Do Investors Hold Socially Responsible Mutual Funds? Journal of Finance 72 (6): 2505-2550.

Saeidi, Sayedeh Parastoo, Saudah Sofian, Parvaneh Saeidi, Sayyedeh Parisa Saeidi, and Seyyed Alireza Saaeidi. 2015. How Does Corporate Social Responsibility Contribute to Firm Financial Performance? The Mediating Role of Competitive Advantage, Reputation, and Customer Satisfaction. Journal of Business Research 68 (2): 341-350.

Saunders, Caroline, and Paul Dalziel. 2017. 25 Years of Counting for Nothing: Waring's Critique of National Accounts. Feminist Economics 23 (2): 200-218.

Shenkar, Oded. 2001. Cultural Distance Revisited: Towards a More Rigorous Conceptualization and Measurement of Cultural Differences. Journal of International Business Studies 32 (3): 519-535.

Soroos, Marvin S. 1994. Global Change, Environmental Security, and the Prisoner's Dilemma. Journal of Peace Research 31 (3): 317-322.

Stern, Nicholas. 2008. The Economics of Climate Change. American Economic Review 98 (2): $1-37$.

Susskind, Lawrence, and Saleem H. Ali. 2015. Environmental Diplomacy: Negotiating More Effective Global Agreements. 2nd ed. Oxford: Oxford University Press.

Trump, Donald. 2017. Statement by President Trump on the Paris Climate Accord. Issued 1 June. https://www.whitehouse.gov/briefings-statements/statement-president-trump-paris-climate-accord/. Accessed 8 Feb 2018.

UIA. 1988. Yearbook of International Organizations, Volume 25, 1988-89. Munich: K. G. Saur for Union of International Associations. 
. 2001. Yearbook of International Organizations, Volume 38, 2001-02. Munich:

K. G. Saur for Union of International Associations.

UNCTAD. 2017. World Investment Report 2017: Investment and the Digital Economy.

New York: United Nations Conference on Trade and Development.

United Nations. 2001. Road Map towards the Implementation of the United Nations

Millennium Declaration. Report of the Secretary General to the 56th Session of the

General Assembly. www.un.org/documents/ga/docs/56/a56326.pdf. Accessed 28 Feb 2018.

2015a. The Millennium Development Goals Report 2015. New York: United Nations.

- 2015b. Resolution Adopted by the General Assembly on 25 September 2015.

70th Session of the General Assembly. www.un.org/en/ga/search/view_doc. asp?symbol=A/RES/70/1\&Lang=E. Accessed 28 Feb 2018.

- 2017. World Population Prospects: The 2015 Revision, Key Findings and Advance

Tables. Working Paper No. ESA/P/WP.248, Department of Economic and Social Affairs, Population Division.

- 2018. Promote Sustainable Development. www.un.org/en/sections/what-wedo/promote-sustainable-development/index.html. Webpage Accessed 28 Feb 2018.

Wang, Qian, Junsheng Dou, and Shenghua Jia. 2016. A Meta-Analytic Review of

Corporate Social Responsibility and Corporate Financial Performance: The Moderating Effect of Contextual Factors. Business \& Society 55 (8): 1083-1121.

Waring, Marilyn. 1988. If Women Counted: A New Feminist Economics. San Francisco:

Harper \& Row. Also Published as Counting for Nothing: What Men Value and What

Women Are Worth. Wellington: Allen \& Unwin in association with the Port Nicholson Press.

Weitzman, Martin L. 2007. A Review of the Stern Review on the Economics of Climate Change. Journal of Economic Literature 45 (3): 703-724.

Open Access This chapter is licensed under the terms of the Creative Commons Attribution 4.0 International License (http://creativecommons.org/licenses/by/4.0/), which permits use, sharing, adaptation, distribution and reproduction in any medium or format, as long as you give appropriate credit to the original author(s) and the source, provide a link to the Creative Commons license and indicate if changes were made.

The images or other third party material in this chapter are included in the chapter's Creative Commons license, unless indicated otherwise in a credit line to the material. If material is not included in the chapter's Creative Commons license and your intended use is not permitted by statutory regulation or exceeds the permitted use, you will need to obtain permission directly from the copyright holder.

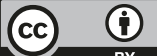

